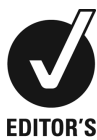

CHOICE

\title{
Cerebral infarction accompanied by cerebral bleeding in patients receiving apixaban
}

\author{
Takao Kato, ${ }^{1}$ Masahiro Kimura, ${ }^{1}$ Moriaki Inoko ${ }^{2}$
}

${ }^{1}$ Department of Cardiovascular Medicine, The Tazuke Kofukai Medical Research Institute, Kitano Hospital, Osaka, Japan ${ }^{2}$ Cardiovascular Centre, The Tazuke Kofukai Medical Research Institute, Kitano Hospital, Osaka, Japan

\section{Correspondence to} Dr T Kato,

takao-kato@kitano-hp.or.jp

Accepted 28 December 2014

\section{DESCRIPTION}

Apixaban is a novel anticoagulant (NOAC) that is superior to warfarin in preventing stroke and minimising bleeding. ${ }^{1}$ A 58 -year-old man was admitted to our hospital for congestive heart failure (CHF) due to a recent myocardial infarction. He had diabetes, hypertension, persistent atrial fibrillation and renal dysfunction. He had no history of hepatitis but was a past heavy drinker. Percutaneous coronary intervention was performed using a second generation drug eluting stent, and administration of $100 \mathrm{mg}$ aspirin, $75 \mathrm{mg}$ clopidogrel and $5 \mathrm{mg}$ apixaban was started. His CHADS2-VASc (CHF, hypertension, diabetes mellitus and vascular event) score was 4 . After 4 months, he complained of dizziness for 3 weeks. Neurological findings apart from dizziness were not observed. MRI revealed a subacute cerebral infarction with haemorrhage at the right temporal lobe (figure $1 \mathrm{~A}, \mathrm{~B})$ without haematoma on CT (figure 1C). The HAS-BLED score was 1 (antiplatelet drug). However, careful reassessment before starting apixaban revealed that prothrombin time was slightly prolonged (figure 2). With a decreased platelet count, liver dysfunction was suspected. Finally, CT revealed decreased liver volume and the presence of liver cancer. CHF often accompanies liver dysfunction. ${ }^{2}$ Liver function was carefully examined as apixaban is partially metabolised to CYP3A4/5 in the liver. Because the risk of cerebral infarction and intracranial haemorrhage during NOAC treatment seems to be small to moderate, ${ }^{13}$ mild symptoms without neurological deficit may need to be carefully assessed. Apixaban and aspirin were continued, and clopidogrel was discontinued, taking into consideration the risks and benefits.

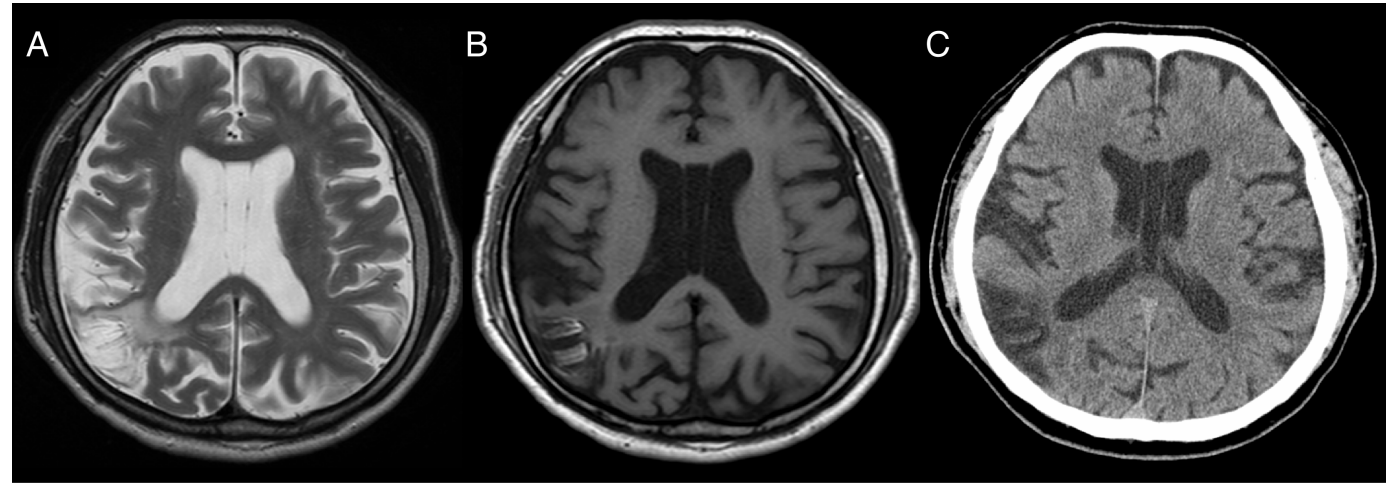

Figure 1 ( $A, B$ ) High intensity on T2 weighted (A) and low intensity on T1 weighted (B) MRIs, indicating subacute haemorrhage accompanied by cerebral infarction. (C) CT image.

\begin{tabular}{|c|c|c|c|c|c|c|c|}
\hline $\begin{array}{c}\text { Before } \\
\text { administration }\end{array}$ & & & & At onset & & & \\
\hline $\mathrm{Bp}(\mathrm{mmHg})$ & $100 / 70$ & ALT (U/L) & 43 & $\mathrm{Bp}(\mathrm{mmHg})$ & $109 / 70$ & ALT (U/L) & 34 \\
\hline APTT (s) & 29.7 & $\mathrm{TP}(\mathrm{g} / \mathrm{dL})$ & 7.2 & APTT (s) & 35.7 & $\mathrm{TP}(\mathrm{g} / \mathrm{dL})$ & 7.2 \\
\hline PT (INR) & 1.14 & ALB (g/dL) & 3.8 & PT (INR) & 1.46 & ALB (g/dL) & 3.6 \\
\hline Cre $(\mathrm{mg} / \mathrm{dL})$ & 1.25 & T-chol (mg/dL) & 237 & Cre (mg/dL) & 1.71 & T-chol (mg/dL) & 147 \\
\hline BUN (mg/dL) & 16.7 & $\mathrm{PLT}\left(/ \mu \mathrm{L}, \mathrm{x} 10^{4}\right)$ & 15.1 & BUN (mg/dL) & 26.7 & $\mathrm{PLT}\left(/ \mu \mathrm{L}, \times 10^{4}\right)$ & 9.8 \\
\hline AST (U/L) & 83 & & & AST (U/L) & 39 & & \\
\hline
\end{tabular}

To cite: Kato T, Kimura $\mathrm{M}_{\text {, }}$ Inoko M. BMJ Case Rep Published online: [please include Day Month Year] doi:10.1136/bcr-2014208965

Figure 2 Summary of laboratory findings. ALB, albumin; ALT, alanine aminotransferase; APTT, activated partial thromboplastin time; AST, aspartate transaminase; Bp, blood pressure; BUN, blood urea nitrogen, Cre, creatinine; PLT, platelet; PT, prothrombin time; T-chol, total cholesterol; TP, total protein. 


\section{Learning points}

- Due to administration of new drugs, complications related to apixaban administration are seldom encountered by the next cardiologist; hence experiences should be shared between cardiologists.

- Because the risk of cerebral infarction and intracranial haemorrhage during novel anticoagulant treatment seems to be small to moderate, mild symptoms without neurological deficit may also need to be examined during follow-up.

- Liver function, along with renal function, should be carefully assessed and monitored during apixaban treatment.
Contributors TK wrote the manuscript, MK collected the data, and MI supervised. Competing interests None.

Patient consent Obtained.

Provenance and peer review Not commissioned; externally peer reviewed.

\section{REFERENCES}

1 Hylek EM, Held C, Alexander JH, et al. Major bleeding in patients with atrial fibrillation receiving apixaban or warfarin: The ARISTOTLE Trial (Apixaban for Reduction in Stroke and Other Thromboembolic Events in Atrial Fibrillation): Predictors, characteristics, and clinical outcomes. J Am Coll Cardiol 2014;63:2141-7.

2 Kato T, Niizuma $S$, Inuzuka $Y$, et al. Analysis of liver metabolism in a rat model of heart failure. Int J Cardiol 2012;161:130-6.

3 Shah R, Shah D, Koganti S, et al. Intracerebral haemorrhage, anticoagulation and mechanical heart valves: what should I do next? BMJ Case Rep. Published: 26 Jun 2013. doi:10.1136/bcr-2013-008639

Copyright 2015 BMJ Publishing Group. All rights reserved. For permission to reuse any of this content visit http://group.bmj.com/group/rights-licensing/permissions.

BMJ Case Report Fellows may re-use this article for personal use and teaching without any further permission.

Become a Fellow of BMJ Case Reports today and you can:

- Submit as many cases as you like

- Enjoy fast sympathetic peer review and rapid publication of accepted articles

- Access all the published articles

- Re-use any of the published material for personal use and teaching without further permission

For information on Institutional Fellowships contact consortiasales@bmjgroup.com

Visit casereports.bmj.com for more articles like this and to become a Fellow 